\title{
Research on Intermodal External Costs of International Container
}

\author{
Wei Ying \\ Nanyang Polytechnic Institute; Nanyang, 473000 \\ hunter2011@foxmail.com
}

Keywords: The Belt and Road; Intermodal containers; External costs; Monetization; Model

\begin{abstract}
The Belt and Road" strategic concept is inseparable from the support of transport, and intermodal container is an effective way to solve the problem of sustainable transport over long distances. "Chongqing New Europe" channel as the cross-border trade of goods multimodal transport channels to container rail transport way for "along the way" alternative development paths. Intermodal transport external cost is an important reference for policy-making, but the lack of in-depth study, empirical study less. Based on the analysis of multimodal transport external costs, "Chongqing New Europe" intermodal rail transport external costs compare with the sea. This paper presents the structural model of the multimodal transport external cost, the establishment of cost model can characterize the damage factor, application of damage cost method factor monetization, end use cost model for Shanghai to Duisburg two multimodal approach way were compared. The results showed that the external costs of waterway transport unit minimum, followed by rail transport, again are road transport, which should give priority to the main transport waterway transport, multimodal transport emissions and costs of each mode of transport in the external account are the largest proportion of the total cost.
\end{abstract}

\section{The Introduction or Background}

In the new normal, my country "The Belt and Road" strategic concept, to promote national and regional economic development have provided favorable conditions. In view of this, the transport corridors cross-border trade of goods and services urgently need to be able to provide a high level of transport services. To achieve high quality of service on the entire transport corridor in the true sense, the external costs of transport must be reasonable imputation. Transport external costs reasonable monetization has a profound effect on the sustainable development of the transport industry. From the social point of view, we analyze the social costs of inter-city road transport, obtained $13.2 \%$ of the external costs of the internal cost of conclusions ${ }^{[1]}$.

The use of geographic information systems in Belgium recorded information about the transport of goods as the simulation input, external cost estimate from five aspects of air pollution, noise, traffic congestion, accidents and damage to infrastructure caused. Road and multimodal transport social costs were constructed model and calculate the marginal cost. Milan also established a full cost model of the above two modes of transport. Cathy made the cost of internal and external problems, which is a reasonable shipping price, then an important condition. Open "Chongqing New Europe" is a major thoroughfare in Shanghai to Duisburg Intermodal cargo area of international trade opened up a new path, to share some of the goods of traditional channels. Shanghai Region - demand for transport services by Duisburg area at the time of these two transport corridor to make decisions, we must consider factors external costs, the only way to make Shanghai Region - Germany Duisburg area transportation structure rationalization ${ }^{[2]}$.

\section{The Multimodal Transport External Costs}

Transport external costs is part of the social costs can't be ignored, but in calculating the transportation costs, costs only consider transport-related activities, these costs are internal in nature, but society as a whole, transportation costs also include the cost of traffic accidents, noise costs, emission costs and congestion costs. Analysis of multimodal transport external costs, it is necessary to learn more about the composition of its geospatial distribution and external costs. Multimodal 
transport consists of three phases: collection of goods, transport and distribution mains, so multimodal total external costs can be according to formula calculation ${ }^{[3]}$.

$$
T C=T C_{1}+X T C_{2}+Y T C_{3} \quad(1)
$$

When $\mathrm{X}=1$, multimodal transport including rail transportation; $\mathrm{X}=0$ Where a multimodal transport does not include rail transport. When $\mathrm{Y}=1$, the multimodal transport including sea transport; $\mathrm{Y}=0$ Where a multimodal transport does not include sea transport.

With Chinese entry into the automobile age, the economic losses caused by traffic accidents is getting bigger, mainly in accident casualties, damaged facilities, four cargo damage and consume public resources and so on, they are not a direct expenditure of enterprises. In this paper, the method adopted to calculate accident costs estimates, that is, for a certain geographical area, select the four casualties in accidents grade general contracting periodic time within a comprehensive, direct losses and functions plus processing costs can constitute a cause of accident costs. Based on the above analysis model can be obtained as follows:

$$
\mathrm{TC}_{\mathrm{ai}}=\mathrm{N}_{\mathrm{fi}} \mathrm{C}_{\mathrm{fi}}+\mathrm{N}_{\mathrm{si}} \mathrm{C}_{\mathrm{si}}+\mathrm{N}_{\mathrm{mi}} \mathrm{C}_{\mathrm{mi}}+\mathrm{N}_{\mathrm{li}} \mathrm{C}_{\mathrm{li}}+\mathrm{C}_{\mathrm{ei}}+\mathrm{C}_{\mathrm{di}}
$$

Where: $\mathrm{TC}_{\mathrm{ai}}$ : total cost of the I year; $\mathrm{N}_{\mathrm{fi}}$ : deaths; $\mathrm{N}_{\mathrm{si}}$ : the number of seriously injured; $\mathrm{N}_{\mathrm{mi}}$ : the number of moderate injuries; $\mathrm{N}_{\mathrm{li}}$ : I year by the number of minor injuries; $\mathrm{C}_{\mathrm{fi}}$ : the unit cost of death; $\mathrm{C}_{\mathrm{si}}$ : the unit cost was seriously injured; $\mathrm{C}_{\mathrm{mi}}$ : by moderate injury unit costs; $\mathrm{C}_{\mathrm{li}}$ : Unit costs suffered minor injuries; $\mathrm{C}_{\mathrm{ei}}$ : direct economic loss; $\mathrm{C}_{\mathrm{di}}$ : administrative costs of handling the traffic accident. After the accident the total cost of a region imputation, this paper assessed the basis for selecting the amount of turnover, the first unit cost of accidents:

$$
\mathrm{UC}_{\mathrm{ai}}=\frac{\mathrm{TC}_{\mathrm{ai}}}{\mathrm{TO}_{\mathrm{i}}}
$$

Where: $\mathrm{UC}_{\mathrm{ai}}$ : i-unit cost of accidents; $\mathrm{TC}_{\mathrm{ai}}$ : Total cost; $\mathrm{TO}_{\mathrm{i}}$ : turnover.

According to related statistics report said engine output noise of traffic analysis has become an important source of pollution, but also mobility. Noise can cause hearing loss, stress and insomnia and other conditions, and induced major diseases. The cost of disease treatment needs, and therefore constitute a part of the external costs of transport. The calculation is as follows:

$$
\mathrm{TC}_{\mathrm{n}}=\mathrm{WTP}+\mathrm{VAR}+\mathrm{C}_{\mathrm{me}}
$$

Where: $\mathrm{TC}_{\mathrm{ns}}$ : noise external costs; WTP: willingness to pay victims groups; VAR: heart disease death risk costs; $\mathrm{C}_{\mathrm{me}}$ : the cost of treatment of other diseases

Intermodal cargo collection and distribution stages used trucks typically diesel fuel, exhaust emissions contain these gases will induce air pollution and the greenhouse effect. Engine exhaust emissions have engine itself effectiveness and fuel composition determined, the emission rate as shown in equation.

$$
\mathrm{R}=\mathrm{C}_{\mathrm{f}} \times \mathrm{E}_{\mathrm{f}}
$$

Where: R: emission rate, $\mathrm{C}_{\mathrm{f}}$ : the amount of emissions per unit of energy waste; $\mathrm{E}_{\mathrm{f}}$ : a unit of fuel energy released. The truck fuel consumption depends on the performance of the truck itself, while under other conditions the same situation, the impact of the load and speed of the fuel consumption of the most obvious.

Railroad (railway) locomotives into an internal combustion engine and electric machine (consider the power structure and increase transmission efficiency), as shown in Equation ${ }^{[4]}$.

$$
\begin{gathered}
\mathrm{E}_{\text {内 }}=\mathrm{F} \times \mathrm{d}_{\mathrm{td}} \times \mathrm{R} \times\left(\frac{1}{\mathrm{~L}_{\mathrm{c}} \times \mathrm{U}}\right) \times \mathrm{L} \\
\mathrm{E}_{\text {电 }}=\frac{\mathrm{F} \times \mathrm{d}_{\mathrm{te}}}{\mathrm{T} \times \mathrm{E}_{\mathrm{f}} \times(1-\mathrm{S})} \times \mathrm{R} \times\left(\frac{1}{\mathrm{~L}_{\mathrm{c}} \times \mathrm{U}}\right) \times \mathrm{L} \times \mathrm{r}
\end{gathered}
$$

Where: F:1 km fuel consumption, L / km, T: conversion; $\mathrm{S}$ : transmission loss rate; $\mathrm{r}$ : use of coal for power generation carried ratio..

Under normal circumstances, the cargo ship to the rated power of the drive, to calculate the 
emissions when the main consideration locomotive types and loading conditions, can be expressed as follows:

$$
\mathrm{E}_{\text {船 }}=\left(\mathrm{C}_{\mathrm{f}} \times \frac{\mathrm{EP}}{\mathrm{V}}\right) \times \mathrm{d}_{\mathrm{s}} \times\left(\frac{1}{\mathrm{~L}_{\mathrm{c}} \times \mathrm{U}}\right) \times \mathrm{L}
$$

Where: EP: engine power, $\mathrm{kW}$. Based emission model can be determined to complete some tasks transportation of various gases and total emissions of particulate matter emissions and thus be regarded as unit costs.

$$
\begin{gathered}
\text { 错误!未找到引用源。 } \mathrm{n}=1 \sim 3 \\
\mathrm{EC}_{\text {总 }}=\sum_{\mathrm{j}=1}^{6}\left(\mathrm{E}_{\text {总 } \mathrm{j}} \times \mathrm{C}_{\mathrm{j}}\right) \\
\mathrm{UC}_{\mathrm{e}}=\frac{\mathrm{EC}_{\text {总 }}}{\mathrm{TO}}
\end{gathered}
$$

Intermodal end of the collection and distribution of cargo trucks are usually distributed in dense urban areas and industrial zones, congestion may encounter delays, and at the same time may cause delays to other vehicles, because the cost of delays caused by external costs should imputation: including increased cargo hold costs and human resource costs due to congestion caused. So congestion cost model can be expressed as:

$$
\mathrm{C}_{\mathrm{C}}=\mathrm{V}_{\mathrm{F}} \times \frac{\rho}{365 \times 24} \times \mathrm{D}+\mathrm{C}_{\mathrm{HR}} \times \mathrm{D}
$$

Where: $\mathrm{C}_{\mathrm{c}}$ : Indicates blockage costs; $\mathrm{C}_{\mathrm{HR}}$ due to blockage of the time delay; The corresponding unit cost of congestion ${ }^{[5]}$ :

$$
\mathrm{UC}_{\mathrm{c}}=\frac{\mathrm{C}_{\mathrm{c}}}{\mathrm{TO}}
$$

\section{The Case Analysis}

In this paper, by the Chongqing Shanghai to Germany Duisburg once a transport task, for the two multimodal external cost estimates. Existing $4020 \mathrm{ft}$ containers filled with parts, single-box total weight 20 tons, the total value of goods $\$ 3.2$ million, to gather from around Shanghai transported to Germany after Duisburg surrounding areas. On this path there are two multimodal approach way: one is from Shanghai sea to Hamburg and then transported by train to Duisburg; another one is transported to Chongqing from Shanghai by train, then take the "Shanghai and Chongqing New Europe" big channel to Duisburg.

According to 2010 traffic accident statistics shows that the occurrence of a total of 3,906,164 times national road traffic since 65,225 deaths, 254,075 injured, the direct economic loss of 930 million yuan. According to the national payment standard, paid for death 600,000 yuan, injured 350,000 yuan per capita payment, while the average administrative costs of processing the accident for every 1,000 yuan. The total cost of accidents $=1.33 \times 1011$ yuan, compared to the national freight turnover $4.3 \times 1012$ ton per kilometer, so the unit cost of road accidents is $3.09 \times 10-2$ yuan / ton per kilometer, or $\$ 4.98 \times 10-3 / \mathrm{t} \cdot \mathrm{km}$. According to statistics, in 2010, the waters within our 331 accidents, the death toll reached more than 329 people, causing economic losses of 324 million yuan. Ship traffic accident, the processing fee is generally 15 million yuan, 600,000 yuan death / person. According to the current statistical bulletin shows that water transport turnover of 684 million tons $\mathrm{km}$, calculate the unit cost of $\$ 1.35 \times 10-5 / \mathrm{t} \cdot \mathrm{km}^{[6]}$.

Volvo F16 use road transport vehicles, the average fuel consumption is 0.35 liters $(9.5 \mathrm{kw} \cdot \mathrm{h})$ per kilometer. Engine utilization was 35 percent haul distance of 70 kilometers. According to the engine index shows that the engine produces every $1 \mathrm{~kW} \cdot \mathrm{h}$ of energy emissions CO2665.5g, according to the company can be obtained by the gas discharge rate $\mathrm{R}=2212.78(\mathrm{~g} / \mathrm{L})$, the same way to obtain emission rates of other gases. Truck cargo collection and distribution stages average speed $35 \mathrm{~km} / \mathrm{h}$, corresponding to fuel consumption of $0.35 \mathrm{~L} / \mathrm{km}$, carbon dioxide can be obtained as $\mathrm{E}=2168524.4$, 
emissions of other gases, the results shown in Table 2, again, can be considered on the basis of unit emissions cost of $5.77 \times 10-3(\$ / \mathrm{t} \cdot \mathrm{km})$.

HXD3 electricity use is assumed train locomotive ahead, we can see its rated power $7200 \mathrm{~kW}$, speed of $90 \mathrm{~km} / \mathrm{h}$. From Shanghai to Chongqing $1949 \mathrm{~km}$, from Chongqing to Duisburg's haul of $11179 \mathrm{~km}$. Coal thermal power accounted for about $77.7 \%$ of its transmission loss rate of 93 percent on average, the charge loss rate of $20 \%$. Data released by the apparent emissions of coal are shown in Table 1. Similarly, the train can be calculated emissions per unit cost of $5.23 \times 10-3(\$ / \mathrm{t} \cdot \mathrm{km})$ [7].

Table 1.The coal emission rate

\begin{tabular}{|c|c|c|c|c|c|c|}
\hline Exhaust emissions & $\mathrm{CO}_{2}$ & $\mathrm{CO}$ & $\mathrm{NO}_{x}$ & $\mathrm{SO}_{2}$ & $\mathrm{HC}$ & $\mathrm{PM}$ \\
\hline Emission Rate $(\mathrm{kg} / \mathrm{t})$ & 690 & 0 & 15.6 & 16.5 & 0 & 9.6 \\
\hline
\end{tabular}

Table 2.The transport external costs of per unit

\begin{tabular}{|c|c|c|c|}
\hline $\begin{array}{c}\text { External costs } \\
(\$ / \mathrm{t} \cdot \mathrm{km})\end{array}$ & Road & Railway & Waterway \\
\hline Accident costs & $4.98 \times 10^{-3}$ & $4 \times 10^{-4}$ & $1.39 \times 10^{-5}$ \\
\hline Noise costs & $2.2 \times 10^{-4}$ & $3.3 \times 10^{-3}$ & \\
\hline Emission costs & $5.77 \times 10^{-3}$ & $5.23 \times 10^{-3}$ & $3.3 \times 10^{-4}$ \\
\hline Congestion costs & $3.6 \times 10^{-3}$ & & \\
\hline Total & $1.4 \times 10^{-2}$ & $8.93 \times 10^{-3}$ & $4.09 \times 10^{-4}$ \\
\hline
\end{tabular}

From Shanghai to Hamburg shipping line length $20152 \mathrm{~km}$, rated load 5,000 TEUs vessel utilization is $75 \%$, power, speed. According to the formula, we can calculate the unit cost of emissions for the $3.3 \times 10-4 \$ / \mathrm{t} \cdot \mathrm{km}$.

Within $70 \mathrm{~km}$ around Shanghai radiation area, blocking an average of half an hour. According to Alford-bangs model can be obtained $25 \%$ of the cost of goods time value of the goods, then the time can be calculated hourly cost of goods. Also determine the human cost of $\$ 8 / \mathrm{h}$ according to the Shanghai word level classes. The total two external cost for channel as follows: Route transport to rail transport: 95419.01; Link Transport of Shipping: $10020.11^{[8]}$.

\section{Conclusions}

Based on a simplified intermodal transport network and reasonable assumptions, external hazards losses from traffic accidents, noise and emissions caused by blockage and delays caused cited four aspects of the external costs of transport of goods in-depth analysis, and this construct a mathematical model for the damage characterization factors, the application of damage cost approach to monetization, calculated road transport, rail and sea transport three modes of transport mode of the unit external costs. The proportions of the cost are the largest in the three modes of transport emissions account for their external costs, so from the viewpoint of the rationalization of the transport structure, to internalize the external costs is necessary.

\section{References}

[1] David J. Forkenbrock. External costs of intercity truck freight transportation.Transportation Research Part A, 1999, 33:505-526.

[2] David J. Forkenbrock. Comparison of external costs of rail and truck freight transportation. Transportation Research Part A, 2001, 35:321-337.

[3] M. Beuthe, F. Degrandsart, J-F. Geerts, B. Jourquin. External costs of the Belgian interurban freight tra $\square$ c: a network analysis of their internalization. Transportation Research Part D, 2002, 
7:285-301.

[4] Andrea Ricci, Ian Black. Measuring the marginal social cost of transport. Research in Transportation Economics, 2005, 14:245-285.

[5] Milan Janic. Modelling the full costs of an intermodal and road freight transport network. Transportation Research Part D, 2007, 12:33-44.

[6] Cathy Macharis, Ellen Van Hoeck, Ethem Pekin, Tom van Lier. A decision analysis framework for intermodal transport: Comparing fuel price increases and the internalization of external costs.Transportation Research Part A, 2010, 44: 550-561.

[7] Kenneth A. Small and Erik T.Verhoef . The Economics of Urban Transportation. Taylor \& Francis e-Library, 2007.

[8] Hashem R. Al-Masaeid, Adel A. Al-Mashakbeh, Abdalla M. Qudah. Economic costs of traffic accidents in Jordan. Accident Analysis and Prevention 31, 1999, 347-357. 